BIOFARM

Jurnal Ilmiah Pertanian

ISSN Print: 0216-5430; ISSN Online: 2301-6442

Vol. 16, No. 1, April 2020

\title{
Pengaruh Dosis Mikoriza Dan Macam Varietas Terhadap Pertumbuhan Dan Produksi Kacang Tanah (Arachis hypogaea L.) Dibawah Tegakan Tanaman Karet
}

\section{Effect Of Mycorrhizal Doses And Varieties Of Varieties On Peanut Growth And Production (Arachis hypogaea L.) Under Stands Of Rubber Plants.}

\author{
Kusyanto \\ Program Studi Agroteknologi, Fakultas Pertanian, Universitas Pekalongan \\ Korespondensi Penulis: kusyantogames@gmail.com
}

\begin{abstract}
ABSTRAK
Penelitian bertujuan mengkaji pengaruh dosis mikoriza serta macam varietas yang sesuai untuk pertumbuhan dan produksi tanaman kacang tanah (Arachis hypogaea L.) di bawah tegakan tanaman karet telah dilakukan di Desa Linggoasri, Kecamatan Kajen, Kabupaten Pekalongan. Pada bulan mei sampai juli 2018. Rancangan yang digunakan adalah RAK (Rancangan Acak Kelompok). Faktor dosis mikoriza : $0 \mathrm{~g} / \operatorname{tanaman}$ (D0), 7,5 g/tanaman (D1), $15 \mathrm{~g} / \operatorname{tanaman}$ (D2), 22,5 g/tanaman (D3), faktor macam varietas : Talam 1 (V1), Tuban (V2), Kancil (V3). Data dianalisis dengan uji F dan dilanjutkan dengan uji BNT $5 \%$. Variabel yang diamati tinggi tanaman, jumlah cabang, jumlah daun, jumlah bunga, jumlah polong, berat basah polong, berat kering polong, berat 100 polong, jumlah akar, panjang akar terpanjang, jumlah bintil akar. Dosis mikoriza berbeda nyata dan sangat nyata terhadap variabel jumlah bunga, jumlah polong, berat basah polong, berat kering polong, berat 100 polong, jumlah bintil akar. Dosis terbaik $15 \mathrm{~g} /$ tanaman (D2). Macam varietas kacang tanah berbeda nyata dan sangat nyata terhadap variabel tinggi tanaman, jumlah daun, jumlah cabang, jumlah bunga, jumlah polong, berat basah polong, berat kering polong, berat 100 polong, jumlah bintil akar. Varietas terbaik Talam 1 (V1). Interaksi antara dosis mikoriza dengan macam varietas kacang tanah berbeda nyata terhadap variabel berat basah polong, berat kering polong, berat 100 polong, jumlah bintil akar. Hasil terbaik pada interaksi dosis $15 \mathrm{~g} /$ tanaman dengan Talam 1 (D2V1).
\end{abstract}

Kata kunci : varietas kacang tanah, dosis mikoriza, di bawah tegakan karet

\begin{abstract}
The aim of the study was to examine the effect of mycorrhizal doses and varieties of varieties suitable for growth and production of peanut plants (Arachis hypogaea L.) under stands of rubber plants that had been carried out in Linggoasri Village, Kajen District, Pekalongan Regency. In May until July 2018. The design used is RBD (Randomized Block Design). Mycorrhiza dose factors: $0 \mathrm{~g}$ / plant (D0), $7.5 \mathrm{~g} /$ plant (D1), $15 \mathrm{~g} /$ plant (D2), $22.5 \mathrm{~g} /$ plant (D3), variety factors: Talam 1 (V1), Tuban (V2), Kancil (V3). Data were analyzed by F test and followed by 5\% LSD test. Variables observed were plant height, number of branches, number of leaves, number of flowers, number of pods, pod wet weight, pod dry weight, weight of 100 pods, number of roots, longest root length, number of root nodules. The best doses is $15 \mathrm{~g} /$ plant (D2). The variety of peanut varieties was significantly different and very real to the variable plant height, number of leaves, number of branches, number of pods, pod weight, pod dry weight, weight of 100 pods, number of root nodules. The best varieties of Talam 1 (V1). The interaction between mycorrhiza doses and peanut varieties was significantly different from the pod wet weight variable, pod dry weight, 100 pod weight, number of root nodules. The best results for the interaction doses of $15 \mathrm{~g} /$ plant with Talam 1 (D2V1).
\end{abstract}

Keywords : peanut varieties, mycorrhiza doses, under the stands of rubber plants

\section{PENDAHULUAN}

Kacang tanah (Arachis hypogaea L.) merupakan salah satu komoditas pangan sumber protein dan minyak nabati yang bernilai ekonomi tinggi (Purba, 2012). Kacang tanah berasal dari Brazilia (Amerika Selatan), dan saat ini telah menyebar ke seluruh dunia yang beriklim stropis dan subtropis. Kacang tanah masuk ke Indonesia pada abad ke-17, dibawa oleh pedagang-pedagang Spanyol, Cina, atau Portugis sewaktu melakukan pelayarannya dari
Meksiko ke Maluku setelah tahun 1597. Kacang tanah di Indonesia kini telah menjadi komoditas penting dan strategis, serta bernilai ekonomi tinggi. Pada daerah sentra produksi, seperti Kabupaten Tuban di Jawa Timur, kacang tanah merupakan penyumbang terbesar $(65 \%)$ terhadap total pendapatan petani lahan kering (Sumarno dan Adi, 1995).

Peningkatan produksi kacang tanah lebih banyak ditentukan oleh peningkatan areal panen daripada peningkatan 
produktivitas. Hal ini tercermin dari kecilnya peningkatan produktivitas dalam satu dekade terakhir, dari 1,11 t/ha pada tahun 2002 menjadi 1,25 t/ha biji pada tahun 2012. Penggunaan varietas unggul yang telah dilepas dan teknik budi daya yang baik, produktivitas kacang tanah dapat ditingkatkan lebih dari dua kali lipat.

Salah satu upaya peningkatan pertumbuhan dan produksi kacang tanah dengan pemberian mikoriza. Mikoriza merupakan hubungan simbiotik dan mutualistik (menguntungkan kedua belah pihak)antara jamur nonpatogen dengan selsel akar yang hidup, terutama sel epidermis dan korteks. Jamur memperoleh senyawa organik (terutama gula) dari tanaman, sedangkan tanaman memperoleh keuntungan karena penyerapan unsur hara dan air dapat berlangsung baik. Bagian sistem perakaran tanaman yang terinfeksi adalah bagian akar yang masih muda, Keuntungan dari keberadaan mikoriza yang telah banyak diketahui adalah meningkatkan serapan fosfat oleh tanaman.

Berdasarkan beberapa sumber kajian adopsi teknologi pertanian, terutama varietas unggul kacang, (Parvan, 2012) menyimpulkan beberapa kendala seperti kurangnya akses informasi, risiko gagal panen, luas lahan, akses terhadap kredit, serta kurang tersedianya infrastruktur dan input. Di antara berbagai kendala tersebut, informasi dan ketersediaan benih bermutu varietas unggul baru yang tidak sampai ke petani dan penyuluh tampaknya merupakan faktor utama yang memerlukan perhatian dari pihak terkait. Apalagi kacang tanah termasuk komoditas yang daya tumbuhnya cepat menurun, sedangkan minat petani untuk menggunakan benih berkualitas dan pengelolaan tanaman yang optimal masih tergolong rendah.

Efisiensi proses produksi diantaranya dapat ditempuh dengan cara pemanfaatan sumberdaya lokal sebagai input (misalnya : sebagai bahan pupuk, pestisida, pakan atupun energi) dengan penerapan teknik budidaya yang berpola intregasi seperti sistem pertanian terpadu (Guntoro, 2000 dalam jazilah, 2015). Sistem pertanian terpadu yang dapat diterapkan misalnya : pemanfaatan areal hutan yaitu dengan menanam tanaman pangan di bawah tanaman hutan seperti di bawah tegakan jati, sengon dan sebagainya.

Berdasarkan uraian diatas, maka perlu dilakukan penelitian tentang dosir mikoriza dan macam varietas terhadap pertumbuhan dan hasil produksi kacang tanah di bawah naungan tanaman karet.

\section{METODE PENELITIAN}

Penelitian telah dilakukan di Dukuh Linggo, Desa Linggoasri, Kecamatan Kajen Kabupaten Pekalongan Jawa Tengah yang memiliki ketinggian \pm 700 meter diatas permukaan laut (mdpl). Selama 3 bulan yaitu mulai bulan Mei 2018 sampai dengan Agustus 2018. Rancangan yang digunakan dalam penelitian ini adalah RAK (Rancangan Acak Kelompok). Faktor pertama yaitu dosis mikoriza yang terdiri atas 4 taraf yaitu 0 gram, 7,5 gram, 15 gram, 22,5 gram dan faktor kedua macam varietas kacang tanah yang terdiri atas 3 taraf yaitu Talam 1, Tuban, Kancil. Masing-masing perlakuan diulang tiga kali sehingga seluruhnya ada 36 satuan percobaan, setiap petak percobaan ditentukan 5 tanaman sampel dengan pola diagonal. Variabel yang diamati yaitu tinggi tanaman per tanaman, jumlah cabang per tanaman, jumlah daun per tanaman, jumlah bunga per tanaman, jumlah polong per tanaman, berat basah polong per tanaman, berat kering polong per tanaman, berat 100 polong per petak, jumlah akar per tanaman, panjang akar terpanjang per tanaman, dan jumlah bintil akar per tanaman.

Data yang diperoleh dianalisis dengan uji $F$, jika diantara faktor yang dicoba terdapat perbedaan nyata maka analisis dilakukan dengan uji BNT, untuk macam varietas kacang tanah diuji menggunakan kontras orthogonal sedangkan dosis mikoriza dilanjutkan dengan uji Regresi.

\section{HASIL DAN PEMBAHASAN Pengaruh Dosis Mikoriza}

Hasil penelitian menunjukan bahwa dosis mikoriza berpengaruh nyata terhadap variabel jumlah bunga per tanaman, jumlah polong per tanaman dan berpengaruh sangat nyata terhadap variabel berat basah polong per tanaman, berat polong kering per tanaman, berat 100 polong per petak dan jumlah bintil akar per tanaman pada pertumbuhan dan produksi kacang tanah yang di tanam di bawah tegakan tanaman karet. Dosis 15 gram per tanaman merupakan 
dosis yang terbaik.

Husin et al., (2012) mengatakan mikoriza menghasilkan enzim fosfatase dari tubuhnya yang dapat membantu tersedianya fosfor $(\mathrm{P})$ yang tidak tersedia menjadi tersedia bagi tanaman sehingga pada akhirnya meningkatkan penyerapan hara $\mathrm{P}$ oleh tanaman. Mikoriza dapat membantu mengatasi masalah ketersediaan fosfat melalui dua cara, pengaruh langsung melalui jalinan hifa eksternal yang diproduksinya secara intensif sehingga tanaman bermikoriza akan mampu meningkatkan

Tabel 1. Angka rata-rata dan Analisis Statistik Data Komponen Pengaruh Dosis Mikoriza dan Macam Varietas

\begin{tabular}{lcccccc}
\hline \multicolumn{1}{c}{ Perlakuan } & $\begin{array}{c}\text { Tinggi } \\
\text { tanaman } \\
(\mathrm{cm})\end{array}$ & $\begin{array}{c}\text { Jumlah } \\
\text { cabang } \\
\text { (buah) }\end{array}$ & $\begin{array}{c}\text { Jumlah } \\
\text { daun } \\
\text { (buah) }\end{array}$ & $\begin{array}{c}\text { Jumlah } \\
\text { bunga } \\
\text { (buah) }\end{array}$ & $\begin{array}{c}\text { Jumlah } \\
\text { polong } \\
\text { (buah) }\end{array}$ & $\begin{array}{c}\text { Berat } \\
\text { basah } \\
\text { polong } \\
\text { (gram) }\end{array}$ \\
\hline Dosis mikoriza & & & & & & \\
D0 = tanpa dosis & 34,84 & 3,82 & 17,47 & $9,22 \mathrm{a}$ & $10,73 \mathrm{a}$ & $19,02 \mathrm{a}$ \\
D1 = dosis 7,5 gram & 35,49 & 3,96 & 17,36 & $9,47 \mathrm{ab}$ & $10,98 \mathrm{ab}$ & $19,36 \mathrm{~b}$ \\
D2 = dosis 15 gram & 35,09 & 4,07 & 17,67 & $9,64 \mathrm{~b}$ & $11,13 \mathrm{~b}$ & $19,53 \mathrm{~b}$ \\
D3 = dosis 22,5 gram & 35,04 & 4,00 & 17,29 & $9,49 \mathrm{ab}$ & $11,04 \mathrm{~b}$ & $19,49 \mathrm{~b}$ \\
\hline Macam varietas & & & & & & \\
V1 = Talam 1 & $35,50 \mathrm{~b}$ & $4,23 \mathrm{~b}$ & $17,73 \mathrm{~b}$ & $9,88 \mathrm{~b}$ & $11,53 \mathrm{~b}$ & $19,73 \mathrm{~b}$ \\
V2 = Tuban & $35,03 \mathrm{ab}$ & $3,88 \mathrm{a}$ & $17,32 \mathrm{a}$ & $9,30 \mathrm{a}$ & $10,77 \mathrm{a}$ & $19,23 \mathrm{a}$ \\
V3 = Kancil & $34,82 \mathrm{a}$ & $3,77 \mathrm{a}$ & $17,28 \mathrm{a}$ & $9,18 \mathrm{a}$ & $10,62 \mathrm{a}$ & $19,08 \mathrm{a}$ \\
\hline
\end{tabular}

kapasitasnya dalam menyerap unsur hara dan air dan pengaruh tidak langsung. Mikoriza dapat memodifikasi fisiologis akar sehingga dapat mengeksresikan asam-asam organik dan fosfatase asam ke dalam tanah. Fosfatase asam merupakan suatu enzim yang dapat mamacu proses mineralisasi P organik dengan mengkatalisis pelepasan $P$ dari kompleks organik menjadi kompleks anorganik.paling banyak diproduksi adalah auksin.
Poerwanto (2003), menyatakan bahwa fungsi fosfor sebagai penyusun karbohidrat dan penyusun asam amino yang merupakan faktor internal yang mempengaruhi induksi pembungaan. Kekurangan karbohidrat pada tanaman dapat menghambat pembentukan bunga. Kolonisasi mikoriza pada bintil akar tanaman dapat memperluas bidang penyerapan bintil akar dengan adanya hifa eksternal yang tumbuh dan berkembang

Tabel 2. Angka rata-rata dan Analisis Statistik Data Komponen Pengaruh Dosis Mikoriza dan Macam Varietas

\begin{tabular}{lccccc}
\hline Perlakuan & $\begin{array}{l}\text { Berat } \\
\text { kering } \\
\text { polong } \\
\text { (gram) }\end{array}$ & $\begin{array}{l}\text { Berat 100 } \\
\text { polong } \\
\text { (gram) }\end{array}$ & $\begin{array}{l}\text { Jumlah } \\
\text { akar (buah) }\end{array}$ & $\begin{array}{l}\text { Panjang akar } \\
\text { ter penjang } \\
\text { (cm) }\end{array}$ & $\begin{array}{l}\text { Jumlah } \\
\text { bintil } \\
\text { akar } \\
\text { (buah) }\end{array}$ \\
\hline Dosis mikoriza & & & & & \\
D0 = tanpa dosis & $15,93 \mathrm{a}$ & $131,00 \mathrm{a}$ & 2,40 & 19,64 & $41,27 \mathrm{a}$ \\
D1 = dosis 7,5 gram & $16,38 \mathrm{~b}$ & $132,67 \mathrm{a}$ & 2,29 & 19,58 & $41,84 \mathrm{a}$ \\
D2 = dosis 15 gram & $16,51 \mathrm{~b}$ & $138,22 \mathrm{~b}$ & 2,44 & 19,69 & $45,00 \mathrm{~b}$ \\
D3 = dosis 22,5 gram & $16,40 \mathrm{~b}$ & $136,56 \mathrm{~b}$ & 2,38 & 19,31 & $44,27 \mathrm{~b}$ \\
\hline Macam varietas & $16,72 \mathrm{~b}$ & $137,25 \mathrm{c}$ & 2,55 & 19,78 & $47,30 \mathrm{~b}$ \\
V1 = Talam 1 & $16,15 \mathrm{a}$ & $134,58 \mathrm{~b}$ & 2,37 & 19,37 & $42,03 \mathrm{a}$ \\
V2 = Tuban & $16,05 \mathrm{a}$ & $132,00 \mathrm{a}$ & 2,22 & 19,52 & $39,95 \mathrm{a}$ \\
V3 = Kancil & & &
\end{tabular}

Keterangan : Angka yang diikuti huruf yang sama pada kolom dan baris menunjukkan tidak berbeda nyata menurut uji BNT taraf $5 \%$ 
pada tanaman. Peran $\mathrm{P}$ yang istimewa adalah proses penangkapan energi cahaya matahari dan kemudian mengubahnya menjadi energi biokimia.

\section{Pengaruh Varietas Kacang Tanah}

Hasil penelitian menunjukan bahwa macam varietas berpengaruh nyata terhadap variabel tinggi tanaman per tanaman, jumlah daun per tanaman dan berpengaruh sangat nyata terhadap variebel jumlah cabang per tanaman, jumlah bunga pertanaman,jumlah polong per tanaman, berat basah polong per tanaman, berat kering polong per tanaman, berat 100 polong per petak dan jumlah bintil akar per tanaman pada pertumbuhan dan produksi kacang tanah yang di tanam di bawah tegakan tanaman karet.

Kacang tanah varietas Talam 1 memiliki jumlah bintil akar yang lebih banyak dan penyerapan unsur hara yang lebih baik serta mudah beradaptasi dengan lingkungan, sehingga laju pertumbuhan tanaman menjadi meningkat. Infeksi pada rambut akar yang merupakan titik awal dari proses pembentukan bintil akar. Oleh karena itu, semakin banyak volume akar yang terbentuk, semakin besar pula kemungkinan jumlah bintil akar atau nodul yang terjadi. Hal ini akan berpengaruh terhadap pembentukan polong. Gardner (1991), menyatakan bahwa tanaman yang mempunyai respon terhadap penyerapan unsur hara dan mudah beradaptasi dengan lingkungan, maka pertumbuhana tanaman pada tahap awal akan berlangsung lebih cepat sehingga akan meningkatkan pertumbuhan vegetatif tanaman seperti akar, batang dan daun, akibatnya berpengaruh terhadap peningkatan tinggi tanaman.

Tabel 3. Angka rata-rata Interaksi Pengaruh Dosis Mikoriza dan Macam Varietas terhadap Pertumbuhan dan Produksi Kacang Tanah di Bawah Tegakan Tanaman Karet.

\begin{tabular}{lcccc}
\hline Perlakuan & $\begin{array}{c}\text { Berat basah } \\
\text { polong per } \\
\text { tanaman (gram) }\end{array}$ & $\begin{array}{c}\text { Berat kering } \\
\text { polong per } \\
\text { tanaman (gram) }\end{array}$ & $\begin{array}{c}\text { Berat 100 polong } \\
\text { per petak (gram) }\end{array}$ & $\begin{array}{c}\text { Jumlah bintil akar } \\
\text { per tanaman } \\
\text { (buah) }\end{array}$ \\
\hline D0V1 & $19,67 \mathrm{def}$ & $16,60 \mathrm{def}$ & $132,00 \mathrm{abc}$ & $44,40 \mathrm{bcd}$ \\
D0V2 & $18,93 \mathrm{~b}$ & $15,87 \mathrm{~b}$ & $131,00 \mathrm{ab}$ & $38,93 \mathrm{a}$ \\
D0V3 & $18,47 \mathrm{a}$ & $15,33 \mathrm{a}$ & $130,00 \mathrm{a}$ & $40,47 \mathrm{ab}$ \\
D1V1 & $19,53 \mathrm{cde}$ & $16,60 \mathrm{def}$ & $134,33 \mathrm{bcd}$ & $44,87 \mathrm{~cd}$ \\
D1V2 & $19,27 \mathrm{bc}$ & $16,27 \mathrm{~cd}$ & $132,67 \mathrm{abcd}$ & $39,80 \mathrm{a}$ \\
D1V3 & $19,27 \mathrm{bc}$ & $16,27 \mathrm{~cd}$ & $131,00 \mathrm{ab}$ & $40,87 \mathrm{abc}$ \\
D2V1 & $20,00 \mathrm{f}$ & $16,93 \mathrm{f}$ & $143,67 \mathrm{~g}$ & $50,60 \mathrm{f}$ \\
D2V2 & $19,33 \mathrm{~cd}$ & $16,20 \mathrm{bc}$ & $138,67 \mathrm{ef}$ & $45,20 \mathrm{f}$ \\
D2V3 & $19,27 \mathrm{bc}$ & $16,40 \mathrm{cde}$ & $132,33 \mathrm{abc}$ & $39,20 \mathrm{a}$ \\
D3V1 & $19,73 \mathrm{ef}$ & $16,73 \mathrm{ef}$ & $139,00 \mathrm{f}$ & $49,33 \mathrm{ef}$ \\
D3V2 & $19,40 \mathrm{cde}$ & $16,27 \mathrm{~cd}$ & $136,00 \mathrm{def}$ & $44,20 \mathrm{bcd}$ \\
D3V3 & $19,33 \mathrm{~cd}$ & $16,20 \mathrm{bc}$ & $134,67 \mathrm{~cd}$ & $39,27 \mathrm{a}$ \\
\hline
\end{tabular}

Keterangan : Angka yang diikuti huruf yang sama pada kolom dan baris menunjukkan tidak berbeda nyata menurut uji BNT taraf $5 \%$

Penanaman di bawah tegakan tanaman karet menyebabkan pertumbuhan tanaman lebih tinggi, daunnya lebih lebar, serta jumlah daun dan jumlah cabang lebih sedikit, dibandingkan dengan tanaman yang mendapatkan cahaya maksimal, hal ini karena terbatasnya cahaya yang diterima tanaman.

\section{Interaksi antara Dosis Mikoriza dan Macam Varietas}

Hasil penelitian menunjukan bahwa terdapat interaksi antara dosis mikoriza dengan macam varietas berpengaruh nyata terhadap variabel berat basah polong per tanaman, berat kering polong per tanaman, berat 100 polong per petak dan jumlah bintil 
akar per tanaman pada pertumbuhan dan produksi kacang tanah yang di tanam di bawah tegakan tanaman karet.

Interaksi ini terjadi karena adanya saling mendukung antara pengaruh dosis mikoriza yang dapat meningkatkan kapasitas akar tanaman dalam penyerapan unsur hara (khususnya fosfor) bagi tanaman. Kombinasi antara dosis mikoriza 15 gram dan varietas Talam 1 (D2V1) memberikan hasil yang terbaik. Talam 1 mempunyai jumlah bintil akar yang lebih banyak dan berukuran lebih tinggi serta mempunyai tingkat adaptasi lingkungan yang lebih baik sehingga dapat melakukan penyerapan unsur hara secara optimal. (Hakim dkk, 2000) proses metabolisme tanaman sangat dipengaruhi oleh ketersediaan unsur hara, sinar matahari dan air yang dapat dimanfaatkan oleh tanaman. Apabila ketersediaan unsur hara, sinar matahari dan air cukup maka metabolisme akan berjalan dengan baik sehingga bahan yang dihasilkan untuk membentuk polong seperti protein dan karbohidrat akan meningkat.

Dilihat letak dari tanaman kacang tanah yang ditanam di bawah tegakan tanaman karet, maka kebutuhan hara kurang terpenuhi. Hal ini dikarenakan adanya persaingan dalam penyerapan unsur hara oleh tanaman (Parnata, 2005). Untuk menghindari hal tersebut maka dilakukan pemberian mikroba tanah (mikoriza), sehingga kesuburan tanah tetap terjaga dan kebutuhan hara dalam tanah juga dapat dipenuhi. karena mikoriza dapat meningkatkan ketersediaan dan pemanfaatan unsur ( $\mathrm{P}, \mathrm{Ca}, \mathrm{N}, \mathrm{Cu}, \mathrm{K}$, dan $\mathrm{Mg}$ ) yang dibutuhkan tanaman serta berperan dalam memelihara keseimbangan tanah.

\section{SIMPULAN}

Berdasarkan hasil penelitian dan pembahasan dapat ditarik beberapa simpulan sebagai berikut :

1. Dosis mikoriza berbeda nyata terhadap variabel jumlah bunga, jumlah polong, dan berpengaruh sangat nyata terhadap variabel berat basah polong, berat kering polong, berat 100 polong, jumlah bintil akar. Hasil terbaik yaitu pada dosis mikoriza 15 gram (D2)..
2. Macam varietas kacang tanah berbeda nyata terhadap variabel tinggi tanaman, jumlah daun, dan berbeda sangat nyata terhadap variabel jumlah cabang, jumlah bunga, jumlah polong, berat basah polong, berat kering polong, berat 100 polong, jumlah bintil akar. Hasil terbaik yaitu pada varietas talam 1 (V1).

3. Interaksi antara dosis mikoriza dengan macam varietas kacang tanah berbeda nyata terhadap variabel berat basah polong, berat kering polong, berat 100 polong, jumlah bintil akar. Hasil terbaik yaitu pada interaksi dosis mikoriza 15 gram dengan varietas talam 1 (D2V1).

\section{DAFATAR PUSTAKA}

Gardner, F.P, 1991. Fisiologi Tanaman Budidaya. Universitas Indonesia Press, Jakarta.

Hakim, N., M. Yusuf, Nyakpa, Sutopo, G., A.M. Lubis, M.Rusdi, Amin, D., Go Bang Hong dan H. Bailey. 2000. Dasar Dasar IImu Tanah. Universitas Lampung, Lampung.

Husin, Eti Parda., Auzar, S., Kasli. 2012. Mikoriza Sebagai Pendukung Sistem Pertanian Berkelanjutan Dan Berwawasan Lingkungan. Padang: Andalas University Press,

Jazilah. S. 2015. Prosiding Seminar Nasional Pangan, Energi, dan Lingkungan. Pekalongan.

Parnata, S.A, 2005. Pupuk Organik Cair Aplikasi dan Manfaatnya. Penerbit PT Agromedia Pustaka, Jakarta.

Parvan, A. 2012. Agricultural technology adoption: Issues for consideration when scaling-up. The Cornell Policy Review, 2012. Cornell University, Ithaca, NY.

Poerwanto, R. 2003. Budidaya Buah-buahan: Proses Pembungaan dan Pembuahan. Bahan Kuliah. Fakultas Pertanian, IPB. Bogor. 44 hal

Purba, F.H.K. 2012. Potensi pengembangan kacang tanah dalam peluang usaha diberbagai daerah Indonesia. (Online) http://heropurba. Blogspot .com/2012/11/potensi- 
pengembangankacang-tanah-

dalam.html. Diakses pada 26 januari 2018.

Sumarno and M. Muchlish Adi. 1995.

Overview groundnut on-farm research in Indonesia. pp. 111. In T. Adisarwanto, N. Saleh and Sumarno (eds). On-Farm Research for Groundnut and Pigeonpea Production Technique in Indonesia. Collaborative Res. CRIFC and CLAN/ICRISAT. MARIF, Malang. $130 \mathrm{p}$. 